\title{
Sixth Annual North American Labor History Conference, October 18-20, 1984-Wayne State University
}

\section{Christopher Johnson and Thomas Klug}

Wayne State University

This year the conference theme was "The Human Impact of Deindustrialization: History and Theory." The purpose was to bring together people dealing with the contemporary crisis-from labor, business, and community programs as well as academic economists, sociologists, and political scientists-and historians who have done research on regional economic decline and its implications. The hope was to develop a broader and more theoretical understanding of the problem. If reactions from participants and the audience are any indication, the dialogue turned out to be quite fruitful.

We began with views from the trenches. Ed Mann, former president of Youngstown's steelworkers' Local 1462, retraced the road to oblivion of work in steel in his city. The lessons that he drew were numerous: the ease with which a great company can withdraw its capital from an area and move it elsewhere (indeed out of the industry altogether); the mistake made long ago by unions in not fighting more vigorously against management rights clauses in their contracts; the International's inability to respond meaningfully to the shock of plant closings other than by working for "a decent funeral"; the massive reverberations that run through the entire community when shutdowns occur, and the need to recognize "community rights" in planning future labor strategy; and finally the need for the rank and file to realize that they "have to take care of themselves."

These themes, in different forms and from different angles, reappeared throughout the conference. Thaddeus Radzialowski (Southwest State, Minnesota) examined the story of the Weirton employee buyout, stressing the long history of paternalism in this company town as a key explanation for the extraordinarily generous terms offered to National Steel and the guarantees-20 percent compensation cuts, no raises and no strikes for six years, and management domination of policy-offered to investors. Peter Friedlander (Wayne State) then mapped the complex recent history of deindustrialization in Metropolitan Detroit, demonstrating above all the widening socioethnic net of unemployment and socially disintegrative poverty. The white working class of outer Detroit and various suburbs along the industrial corridors of the area is 
beginning to face hardship similar to that of blacks. Although racism currently tends to reorient their rage, white ethnics and southerners are beginning to realize, Friedlander argued, that their privileged status is fragile indeed. The first statement of a key thread running through the conference-the segmented labor market and the expansion of secondary market jobs (along with the reserve army) at the expense of those in the formerly prosperous, unionized primary segment-was thus presented. Jeremy Brecher's commentary, focussing on the political implications of these grim scenarios, stressed the need for action in three ways: the development of new forms of labor organizing which bridge the segmented market and draw upon the lessons outlined by Mann and others; active confrontation by organized labor of American foreign policy supporting oppressive regimes guaranteeing low-wage industrial export platforms abroad, particularly in the Third World; and merging of community and labor interests in the building of reindustrialization "from below." In general, all underlined the extraordinary power and adaptability of capitalism and recognized that although the current crisis has its peculiar characteristics, regional deindustrialization is nothing new.

Aspects of that long historical record, sometimes in direct comparison to contemporary examples, occupied the following sessions. It can perhaps be argued that the history of capitalistic development, from its inception in late Medieval Europe, is fundamentally the history of economic regions and their interrelationships. Historians Russell Menard (Minnesota) and Charles Tilly (New School for Social Research) examined, respectively, the problem of colonial underdevelopment and metropolitan industrial growth. Their arguments gave some support to the "world system" concepts of Immanuel Wallerstein, Andre Gunder Frank, and Eric Williams by stressing regional disparities along the core-periphery fault-line, internal regional differentiation in preindustrial France according to two hierarchies, economic and administrative, and the ways their interplay potentially influenced industrial growth and accompanying social conflict in the nineteenth century. Both therefore emphasized the importance of the state, its power and structures, as a factor influencing the economic destinies of regions-that they do not operate, in other words, on economic laws alone. Commentator Domenico Sella (Wisconsin), although agreeing that power and profit were always interrelated in European economic development, remained unconvinced that the Williams thesis could be refurbished and urged Tilly to clarify the interconnections that he was examining.

Regional decline in the industrial setting occupied the subsequent four sessions. "Relocation decision-making in 20th-century America" generated a number of interesting points. Lucy Mathiak (Wisconsin, history), studying New England cotton textiles' move to the South, stressed its gradual nature. Companies maintained plants in both areas and slowly shifted operations as machinery needs declined. This factor was developed by commentator Robert Liebman into an important general thesis: The supply and distribution net- 
works are what often anchor an industry in an area; it will stay there as long as those networks are needed and viable. Sociologist Michael Schwartz, reporting on the large study of New York plant closings from 1960 to 1980 currently going on at Stony Brook, emphasized that larger plants and industries susceptible to corporate merger seem to be those most rapidly disappearing; huge conglomerates can easily divest themselves of marginal operations, take the tax gains, and move operations elsewhere. Liebman also noted that these victims of corporate takeover no longer need be connected to regional networks. Commentator John Hekman, an economist, argued that all processes described are part of the inexorable dynamics of capitalism and the laws of capital mobility. Ultimately, labor must follow the jobs. This perspective, of course, posed concretely the realities of the late twentieth century and, as a member of the audience argued (agreeing with Friedlander especially), bears within it the potential for revolutionary upheaval as beleaguered communities reject the entire edifice.

The next session, however, looked at reemployment in areas where deindustrialization has taken its toll. Tessie Liu (Michigan), in a fascinating papér centering on the Choletais in late nineteenth-century France, traced the redevelopment of cottage industry and argued that hand and machine industry could long coexist in low-wage areas where people submitted to poverty rather than moving. Sociologist Paul Schervish (Boston College) laid out aspects of his research on laid-off Detroit auto workers. Here, although a large percentage (72 percent) returned to the auto plants with the revival, those that did not entered lower paying, usually secondary labor market jobs, generally in retailing. The long period of unemployment at personal income levels well below auto pay and requiring family supplemental income, he argues, conditioned former autoworkers for their new role. Schervish thus sheds new light on the role of the reserve army-unemployment as a transitional status in the pathways of downward mobility. Commentator Barry Bluestone (B.C.) underlined the importance of both papers in dealing with rather unexplored territory and emphasized that the conditioning that occurs in both cases poses an important impediment to effective labor organizing among these people. (Robert Spencer, president of the Detroit Economic Growth Corporation, commented at a later session, however, that one of the tasks of labor, business, and politicians is to "prepare" people for the experience of downward mobility.) Bluestone also made the extremely important point that we have to abandon "linear" views of capitalist development; the reconversion to sweated and cottage industry, where cost-price and social factors make it feasible, is proof of it. On the other hand, it should be noted (and was not) that the inherent tendencies in capitalism toward narrowing profit margins and declining wages seems to find validation when one examines current processes. The world-wide scope of the issue -outsourcing, competition in distant low-wage labor markets-promises "to bring the Third World home," as Friedlander put it. 
At this point, the focus shifted toward responses to de-industrialization. Christopher Johnson (Wayne State) examined the dilemma of Lower Languedoc socialism as the region faced the collapse of industry and the rise of winemaking as the single source of economic sustenance. Increasingly it veered away from class-struggle ideology and toward a kind of regional boosterism with Occitan nationalist overtones that emphasized worker-grower cooperation in "defense of the interests of the Midi." Kim Lacey Rogers (Dickinson) looked at punk rock as a response to economic despair in Britain's collapsing industrial areas. She emphasized that although its strident protest was classconscious and indeed revolutionary, it was deeply flawed by its misogynist, antireproductive character that, she argued, was rooted in the cult of masculinity inherent in bourgeois cultural tradition. Chris Waters's fascinating commentary linked the two cautionary tales by looking at them as examples of false consciousness but wondered in fact whether regional nationalism or culturaldespair protest were as diversionary as the authors seemed to imply. An interesting, if inconclusive, debate followed, and Johnson noted that current Languedoc leftist regionalism eschews separatism, arguing instead for "autogestion." The concept of community defense (such as in the British miners' strike today) meshes well with such notions.

The next session examined the Canadian experience of deindustrialization. David Moulton, Chris Waddell, and Leslie Dalagren (Toronto) questioned the Waffle group's extreme position on the U.S. multinationals' withdrawal of capital as the basis for current Canadian ills, but still stressed Canada's semicolonial status vis-à-vis the U.S. James Thwaites (Laval) and Robert Babcock (Maine), the commentator, argued for a less nationalistic perspective, placing Canada in the Pantheon of the advanced industrial nations, one undergoing regional industrial decline and transformation in the typical manner. Daniel Drache (York) responded with arguments, based on new data for Ontario, underlining Canada's disastrous situation in the face of U.S. corporate ownership of industry there. Although the nationalist terms of the debate made one reflect on the previous session, this discussion also allowed one to think of the potential for uncontrollable deindustrialization in other industrial client states around the world now and in the future.

Technological displacement and its impact on trade unions in the twentieth century was the subject of the following session. Patricia Cooper's (Drexel) overview of the tobacco workers showed this industry's drastic shift from the primary to the secondary segment of the labor market in its recruitment of workers that occurred with the rise of the 5-cent cigar rolled on the new machines perfected in 1918. Cigarettes and Prohibition further undermined the industry; then cigar manufacturers, with general success despite resistance, managed to pull the rug out from under the old craft union by relying more and more on the feminine and immigrant labor market. Grace Palladino traced the rise of the automatic elevator and the imaginative tactics of the Ser- 
vice Workers Union to resist it, but stressed in general the massive problems of organizing in the service sector of the economy, which undergoes constant organizational and technological change and recruits labor in a random fashion.

To this point, the conference was, as several attendees put it, "all gloom and doom." But then Elaine Barnard (Simon Fraser) told the remarkable story of the British Columbia Telephone workers' 1981 struggle to regulate the introduction of new technology. What they did, in the manner of Lipp industries in France, was literally to take over the company and run it without management. The Vancouver labor movement assisted with a one-day general strike, and general community support was immense. They won their demands and showed the world how insignificant management's function was in the actual direction of production. Although it may be easy to hate the telephone company, the backing the strikers received from the consumers was remarkable and again shows that our perception of labor's public image may not be what we are conditioned by the press to think. All in all, it was a remarkable example of what can happen and should be more widely known. Nora Faires's comments asked for more careful analysis of skill levels and ethnic and gender differentials in all three cases, but especially in how these potentially divisive factors were handled in the B.C. Tel affair.

The final session, with commentary by Douglas Fraser and Robert Spencer, explored modes of revitalization. The focus was on the two most obvious mechanisms: national industrial policy and employee/community ownership programs. Charles Crone of Comerica Bank provided concrete proof (if any were needed) that banks are not charitable institutions. Comerica was one of the investors in the Weirton buyout, and Crone's analysis made it clear that without the kinds of guarantees discussed earlier, they would not have made their loan. Particularly important to them was the continuity of management and the minority status of workers and union people on the board of directors. Such are the realities faced by many employee ownership programs and no doubt one of the reasons why Deborah Olson (Michigan Employee Ownership Center) stressed that their work, which focusses on developing truly cooperative ventures, has so far been largely with small businesses. Olson emphasized, however, that current employee ownership legislation provides tax incentives of a substantial nature, and she foresaw significant developments in the future. She also returned to a central theme of the conference: the importance of labor-community cooperation in facing deindustrialization. Crone, of course, reminds us that the "community" also includes bankers.

The national industrial policy debate really revolved around whether or not it was the answer, not its possible content. Richard Hill presented an excellent overview of policy initiatives on all levels, but emphasized the great importance of regional planning - the Great Lakes area in his case. Any national plan should begin with the region because, as the conference stressed throughout, the region is the geographical unit in which most economic activity is car- 
ried out. Sharon Zukin, in fact, underlined that French national industrial revitalization policy has largely been ineffective because of the powerlessness of the regions, the absence of regional political institutions that can operate as pressure groups. The net effect has been to neutralize the efforts of the central government to help distraught areas redevelop. Fraser and Spencer took diametrically opposite positions on the question: The one, in favor of a coordinated national policy; the other, fearful that regulation would dissuade capital from locating in targeted areas, opposed to it. Spencer stressed instead the need for capital, labor, and regional politicians to "sit down together" and adjust to the new realities of decline while working to build where possible.

Taken as a whole, the conference papers and comments underline the incredibly difficult political problem posed by regional deindustrialization. Although mass community action and a vital labor movement can make things happen (as at B.C. Tel.), the more usual circumstance is what occurred in Detroit's Poletown conflict (an important film by George Corsetti and Jeanie Wylie, Poletown Lives, was the focus of an evening session). General Motors received a huge tract of urban real estate with appropriate tax abatement from the city government, whose job it was to buy the people out despite widespread resistance by homeowners. Here the labor movement, most community leaders in Detroit, and the Detroit archdiocese did not rally behind the people of Poletown, and they were crushed. Essentially, corporate blackmail succeeded. And where bailouts were successful (Weirton, the Languedoc wine industry), they were on the terms of the capitalists as well. In the end, of course, deindustrialization is nothing more or less than the result of shifts in capital investment patterns. The ultimate challenge for labor and "community," then, is to devise means to control capital mobility. But to do that is to challenge the very essence of capitalism, for what we call deindustrialization is not a disease to be treated, but the heart and soul of the system. 